\title{
Identification among morphologically similar Argyreia (Convolvulaceae) based on leaf anatomy and phenetic analyses
}

\author{
Paweena Traiperm ${ }^{1 *}$, Janene Chow ${ }^{1,2}$, Possathorn Nopun ${ }^{1,2}$, G. Staples ${ }^{3}$ and Sasivimon C. Swangpol
}

\begin{abstract}
Background: The genus Argyreia Lour. is one of the species-rich Asian genera in the family Convolvulaceae. Several species complexes were recognized in which taxon delimitation was imprecise, especially when examining herbarium materials without fully developed open flowers. The main goal of this study is to investigate and describe leaf anatomy for some morphologically similar Argyreia using epidermal peeling, leaf and petiole transverse sections, and scanning electron microscopy. Phenetic analyses including cluster analysis and principal component analysis were used to investigate the similarity of these morpho-types.

Results: Anatomical differences observed between the morpho-types include epidermal cell walls and the trichome types on the leaf epidermis. Additional differences in the leaf and petiole transverse sections include the epidermal cell shape of the adaxial leaf blade, the leaf margins, and the petiole transverse sectional outline. The phenogram from cluster analysis using the UPGMA method represented four groups with an $R$ value of 0.87 . Moreover, the important quantitative and qualitative leaf anatomical traits of the four groups were confirmed by the principal component analysis of the first two components. The results from phenetic analyses confirmed the anatomical differentiation between the morpho-types.
\end{abstract}

Conclusions: Leaf anatomical features regarded as particularly informative for morpho-type differentiation can be used to supplement macro morphological identification.

Keywords: Leaf epidermis, Leaf transverse section, PCA, SEM, Species complex, Stomatal index, UPGMA

\section{Background}

The genus Argyreia Lour., one of the larger genera in Convolvulaceae with approximately 135 species, is mainly distributed in tropical Asia (Staples and Traiperm 2017). During preparation of a nomenclatural review of the genus, we found that some species of Argyreia are quite similar in their vegetative morphology leading to confusion in identification when only leaf and stem characters are available. Species delimitation in Convolvulaceae generally, including Argyreia, is heavily dependent on floral characters; when fully developed flowers are lacking it can be difficult or impossible to identify species precisely.

\footnotetext{
*Correspondence: paweena.tra@mahidol.edu

1 Department of Plant Science, Faculty of Science, Mahidol University,

Rama VI Road, Ratchathewi, Bangkok 10400, Thailand

Full list of author information is available at the end of the article
}

Thus, when specimens with only leaves, or young flower buds, or fruits are all that is available it may not be possible to do more than narrow down the identification to a group of similar species. We have identified several such cases; these seem to represent species-complexes of morphologically similar species, or perhaps single highly polymorphic species. One such group of species includes Argyreia breviscapa (Kerr) Ooststr., Argyreia kerrii Craib, Argyreia suddeeana Traiperm \& Staples, Argyreia variabilis Traiperm \& Staples and two unnamed Argyreia that appear morphologically distinct. Previously we pointed out that some species complexes have similar macro morphological leaf characters (Staples and Traiperm 2008; Traiperm and Staples 2014). In order to explore other characters that might be useful for identification, 
this research investigates foliar micromorphology as a means to identify plants or specimens that lack flowers.

Leaf anatomy of some species in Argyreia had been investigated by Metcalfe and Chalk (1950), SayeedudDin (1953) and Pant and Bhatnagar (1975). Leaf epidermis and stem transverse sections of four Argyreia species [Argyreia nervosa (Burm.f.) Bojer, Argyreia onilahiensis Deroin, Argyreia sericea Dalzell \& A. Gibson and Argyreia splendens (Hornem.) Sweet] were studied by Tayade and Patil (2003, 2012a). A key to species was constructed based on the epidermal characters such as cuticular striations, anticlinal cell walls, and basal cells of trichomes (Tayade and Patil 2003). Recent publication of a new species of Argyreia suggested that leaf epidermal characters, such as the pattern of cutin, can be used to distinguish Argyreia albiflora Staples \& Traiperm from the morphologically similar species Argyreia wallichii Choisy (Staples et al. 2015). Anatomical characters strongly supported species identification in an investigation of Merremia section Xanthips (Pisuttimarn et al. 2013).

Anatomical information has been used for this analysis because it has proven useful and informative in assisting with taxonomic identification and classification in other plants (Thadeo et al. 2014). Leaf anatomical characters from several families also revealed similarities between plant species when using phenetic analysis [cluster analysis (CA) and principal component analysis (PCA)] (Nikolić and Mitić 1991; Breitwieser and Ward 1993; De Faria et al. 2010; Aghababaeyan et al. 2014; Moraes et al. 2011; Thadeo et al. 2014; Arthan et al. 2016; Jayarathna et al. 2016). In Convolvulaceae, particularly the genus Argyreia, phenetic analysis based on leaf anatomy has not been done before. The aim of this research was to study the leaf anatomy of $A$. breviscapa and similar-looking morpho-types and to conduct phenetic analyses using leaf anatomical characters to determine their utility for taxon discrimination and identification.

\section{Methods \\ Plant collections}

Plant materials were collected from their natural habitats for six morpho-types that are similar to A. breviscapa (e.g., A. kerrii, A. suddeeana, A. variabilis, Argyreia 1 and Argyreia 2). For each morpho-type, 1-5 populations were sampled. At least five mature leaves in each population were fixed in a mixture of $70 \%$ ethyl alcohol and $0.05 \%$ glycerol. Voucher specimens were prepared for each morpho-type and deposited at BKF (Table 1). Investigation of the micro-morphological characters was divided into three parts: epidermal surfaces examined by the peeling method; epidermal surfaces viewed with scanning electron microscopy (SEM); and leaf transverse sections prepared by modified paraffin method (Johansen 1940).

\section{Leaf epidermal surfaces}

Mature leaves were selected and peeled by a razor blade. The epidermis was stained with Safranin-O for 10-15 min, and then dehydrated in an ethyl alcohol series, finally mounted with $\operatorname{DePeX}$ for a permanent slide. The stomatal index was calculated according to the method described by Salisbury (1927).

Leaf surfaces were also studied intensively by the scanning electron microscope (SEM). Small pieces of leaf $\left(5 \times 5 \mathrm{~mm}^{2}\right)$ were dehydrated in ethanol series and sonicated to remove unwanted parts from the surfaces. After that, dried samples were coated with platinum-palladium in a sputter coater (Hitachi E-102 Ion Sputter). The cuticular patterns were observed and imaged under a Hitachi S-2500 scanning electron microscope.

Table 1 List of the plant materials used in this study

\begin{tabular}{llll}
\hline No. of accession & Taxa & Voucher specimens & Locality \\
\hline 1 & Argyreia breviscapa (Kerr) Ooststr. & J. Chow and P. Traiperm s.n. & Khon Kaen, Thailand \\
2 & A. kerrii Craib & Staples et al. 1550 & Kanchanaburi, Thailand \\
3 & A. suddeeana Staples \& Traiperm & J. Chow and P. Traiperm 002 & Chiang Mai, Thailand \\
4 & & J. Chow and P. Traiperm 017 & Ratchaburi, Thailand \\
5 & A. variabilis Traiperm \& Staples & J. Chow and P. Traiperm 019 & Ratchaburi, Thailand \\
6 & Argyreia 1 & S. Suddee s.n. & Phetchaburi, Thailand \\
7 & Argyreia 2 & J. Chow and P. Traiperm s.n. & Phetchaburi, Thailand \\
8 & & J. Chow and P. Traiperm 030 & Kanchanaburi, Thailand \\
9 & & J. Chow and P. Traiperm 031 & Kanchanaburi, Thailand \\
10 & J. Chow and P. Traiperm 032 & Kanchanaburi, Thailand \\
11 & J. Chow and P. Traiperm 033 & Kanchanaburi, Thailand \\
12 & J. Chow and P. Traiperm 034 & Kanchanaburi, Thailand \\
13 & J. Chow and P. Traiperm 035 & Kanchanaburi, Thailand \\
\hline
\end{tabular}




\section{Leaf transverse section}

The paraffin method used in this study was modified from Johansen (1940). Leaf samples were cut using a sliding microtome, stained with Safranin-O and counterstained with Fast Green. The tissues were dehydrated using ethanol series and mounted with DePeX.

The leaf characters from the epidermis and the transverse sections were observed using a light microscope, Olympus BX43, and photo-micrographed using an Olympus DP21 camera.

\section{Phenetic analyses}

Thirteen accessions (Table 1) were used in the analysis. Twenty-four leaf anatomical characters (six qualitative and 18 quantitative) were analyzed from leaf surfaces, leaf and petiole transverse sections (Table 2). The qualitative traits were repeatedly observed under light microscopy with five different leaf sample slides per one accession to confirm character stability. For the quantitative characters, each character was measured and means with standard deviations were calculated in ten replicates. For reducing bias in quantitative characters, most of them were expressed in terms of ratios (except blade thickness).

All data were transformed into discrete numbers to score and form the data matrix. The phenetic analyses including CA and PCA were performed. The cluster analysis was conducted based on Unweighted Pair Group Method with Arithmetic Mean (UPGMA) clustering in NTSYS-pc version 2.1 (Rohlf 2000). The similarity between morpho-types resulted in phenogram was estimated by simple matching coefficient (SM). The PCA was performed using Minitab version 16 (2010). The first and second components from PCA were presented for identification of the important anatomical traits.

Table 2 The leaf anatomical characters and character states used in phenetic analyses

\begin{tabular}{|c|c|c|}
\hline Anatomical characters & Character states & Score \\
\hline \multicolumn{3}{|l|}{ Qualitative characters } \\
\hline 1. Epidermal cell wall on adaxial leaf surface & Straight to slightly curved/sinuate & $0 / 1$ \\
\hline 2. Epidermal cell wall on abaxial leaf surface & Straight to slightly curved/sinuate & $0 / 1$ \\
\hline 3. Types of non-glandular trichome on abaxial leaf surface & $\begin{array}{l}\text { Large and small straight trichome/large straight and small } \\
\text { curly trichome }\end{array}$ & $0 / 1$ \\
\hline 4. Shape of petiole & Slightly concave/convex & $0 / 1$ \\
\hline 5. Midrib outline and adaxial curvature & Rounded/acute & $0 / 1$ \\
\hline 6. Leaf margin shape & Rounded/acute & $0 / 1$ \\
\hline \multicolumn{3}{|l|}{ Quantitative characters } \\
\hline 7. Ratio of adaxial leaf epidermal cell size (width: length) & Ratio is less than or equal to $0.7 /$ ratio is more than 0.7 & $0 / 1$ \\
\hline 8. Stomatal index (SI) on adaxial leaf surface & $\mathrm{SI}$ is less than or equal to $6 / \mathrm{Sl}$ is more than 6 & $0 / 1$ \\
\hline 9. Ratio of stomatal size on adaxial leaf surface (width: length) & Ratio is less than or equal to $0.6 /$ ratio is more than 0.6 & $0 / 1$ \\
\hline 10. Ratio of glandular trichome size on adaxial leaf surface (width: length) & Ratio is less than or equal to $0.92 /$ ratio is more than 0.92 & $0 / 1$ \\
\hline 11. Ratio of non-glandular trichome size on adaxial leaf surface (width: length) & Ratio is less than or equal to 0.08 /ratio is more than 0.08 & $0 / 1$ \\
\hline 12. Ratio of abaxial leaf epidermal cell size (width: length) & Ratio is less than or equal to 0.65 /ratio is more than 0.65 & $0 / 1$ \\
\hline 13. Stomatal index (SI) on abaxial leaf surface & $\begin{array}{l}\text { SI is less than or equal to } 15 / \mathrm{SI} \text { is more than } 15 \text {, but less than } \\
\text { or equal to } 30 / \mathrm{SI} \text { is more than } 30\end{array}$ & $0 / 1 / 2$ \\
\hline 14. Ratio of stomatal size on abaxial leaf surface (width: length) & Ratio is less than or equal to 0.75 /ratio is more than 0.75 & $0 / 1$ \\
\hline 15. Ratio of glandular trichome size on abaxial leaf surface (width: length) & Ratio is less than or equal to 0.9 /ratio is more than 0.9 & $0 / 1$ \\
\hline 16. Ratio of non-glandular trichome size on abaxial leaf surface (width: length) & $\begin{array}{l}\text { Ratio is less than or equal to } 0.03 \text { /ratio is more than } 0.03 \text {, but } \\
\text { less than or equal to } 0.04 / \text { ratio is more than } 0.04\end{array}$ & $0 / 1 / 2$ \\
\hline 17. Ratio of epidermal cells size in petiole (width: length) & Ratio is less than or equal to $0.7 /$ ratio is more than 0.7 & $0 / 1$ \\
\hline 18. Ratio of petiole transverse section (width: length) & $\begin{array}{l}\text { Ratio is less than or equal to } 0.82 \text { /ratio is more than } 0.82 \text {, but } \\
\text { less than or equal to } 0.95 / \text { ratio is more than } 0.95\end{array}$ & $0 / 1 / 2$ \\
\hline $\begin{array}{l}\text { 19. Ratio of palisade mesophyll cell size in leaf transverse section (width: } \\
\text { length) }\end{array}$ & Ratio is less than or equal to 0.2 /ratio is more than 0.2 & $0 / 1$ \\
\hline 20. Ratio of spongy mesophyll cell size in leaf transverse section (width: length) & Ratio is less than or equal to $0.7 /$ ratio is more than 0.7 & $0 / 1$ \\
\hline 21. Ratio of adaxial epidermal cell size in leaf transverse section (width: length) & Ratio is less than or equal to $0.7 /$ ratio is more than 0.7 & $0 / 1$ \\
\hline 22. Ratio of abaxial epidermal cell size in leaf transverse section (width: length) & Ratio is less than or equal to $0.7 /$ ratio is more than 0.7 & $0 / 1$ \\
\hline 23. Blade thickness $(\mu \mathrm{m})$ & $\begin{array}{l}\text { Thickness is less than or equal to 208/thickness is more than } \\
208 \text {, but less than or equal to } 248 \text { /thickness is more than } 248\end{array}$ & $0 / 1 / 2$ \\
\hline 24. Ratio of midrib thickness (width: length) & Ratio is less than or equal to $1 /$ ratio is more than 1 & $0 / 1$ \\
\hline
\end{tabular}




\section{Results}

\section{Epidermal cell wall and cuticle}

The patterns of anticlinal cell walls as seen under light microscopy appear straight to slightly curved and sinuate (Table 3). Almost all morpho-types have straight to slightly curved cell walls on adaxial surfaces, except in Argyreia 1, which shows a sinuate pattern of anticlinal cell walls (Fig. 1). Straight to slightly curved cell walls are present on the abaxial side of A. breviscapa and A. variabilis (Fig. 1g, j), whereas the others have sinuate patterns of anticlinal cell walls (Fig. 1h, i, k, l). The cuticular striation is shown on both sides of the lamina in all morphotypes (Fig. 2). However, A. kerrii possesses numerous trichomes on the abaxial leaf surface which interfere with viewing the surface (Fig. 2h).

\section{Type of stomata and stomatal index}

All of the morpho-types have amphistomatous leaves. The stomata on the adaxial leaf surface are anisocytic and paracytic in most of the morpho-types, excluding $A$. kerrii and $A$. variabilis, in which only the paracytic stomatal type was found. Conversely, a paracytic stomatal type presents on the abaxial leaf surface of every morpho-type, whereas A. breviscapa possesses both anisocytic and paracytic stomata (Table 3 ). On the adaxial epidermis the highest stomatal index was observed in $A$. breviscapa and the lowest in $A$. variabilis. On the other hand, the highest stomatal index on the abaxial epidermis was found in A. variabilis and the lowest in Argyreia 1 (Table 3).

\section{Type, density, size and length of trichomes}

Two types of trichomes are present in all morpho-types (Table 3): peltate glandular and simple non-glandular trichomes. Three types of non-glandular trichomes were recognized based on their length and direction: i.e. large straight; small straight; and small curly trichomes were found (Table 3). On their adaxial leaf surfaces, all of the morpho-types possess large and small, straight trichomes (Fig. 3a-f). Similarly on the abaxial leaf surfaces, most morpho-types have large and small straight trichomes excluding $A$. kerrii, which has large straight alternating with small curly trichomes (Fig. $3 g-1$ ). The longest trichomes on the adaxial epidermis occur in A. variabilis, while the shortest ones are in A. suddeeana (Table 3). Meanwhile, the longest trichomes on abaxial epidermis are in $A$. breviscapa and the shortest in A. suddeeana (Table 3).

\section{Transverse section of leaf blade and petiole}

Leaf blades of all six morpho-types have one layer of epidermis with thin cuticle (Fig. 4). Adaxial epidermal cells are irregular to round in shape excluding $A$. variabilis, which has long and narrow shaped cells (Fig. 4d). Argyreia breviscapa, A. kerrii, and A. suddeeana have dark-staining deposits in some of the cells on the adaxial surface (Fig. 5a-c). Palisade and spongy cells are different in shape. Palisade parenchyma is composed of 1-2 cell layers. Most morpho-types have rounded leaf margins (Fig. 4g-i, k, l), except $A$. variabilis, which has acute margins (Fig. 4j) (Table 4).

Outlines of the midrib are convex on the adaxial surface with a single acute to rounded adaxial curvature, while abaxial side are rounded or flattened. Almost all have rounded adaxial curvature (Fig. 5b-f), except $A$. breviscapa (Fig. 5a). Vascular tissue in the midrib is bicollateral type (Fig. 5a-f). Secretory cavities occur in all morpho-types, especially in A. kerrii (Fig. 5b). The largest cross-sectional midrib size is in $A$. variabilis and the smallest in Argyreia 1 (Table 4). Druse crystals are commonly found in the petioles, midribs, and leaf blades of all.

Petiole transverse section outlines are convex in $A$. breviscapa, A. variabilis and Argyreia 2 (Fig. 5g, j, l), while A. kerrii, A. suddeeana and Argyreia 1 show slightly concave outlines on the adaxial surface (Fig. 5h, i, k). Chlorenchyma comprises three to five cell layers in the cortex. Secretory cavities with thin walls are present in the ground parenchyma of all the morpho-types, particularly in $A$. kerrii (Fig. 5h). The vascular tissue of the petioles in all morpho-types consists of three bicollateral bundles. The largest cross-sectional petiole size is shown in A. variabilis and the smallest in Argyreia 1 (Table 4).

\section{Cluster analysis}

The phenogram of Argyreia morpho-types (Fig. 6) using 24 anatomical traits (Table 2) was constructed by UPGMA algorithm, for which the cophenetic correlation coefficient (or $R$ value) was equal to 0.87 . The high $R$ value (>0.8) indicated the suitability of morpho-types clustering. From the phenogram, four major clusters (A, $\mathrm{B}, \mathrm{C}$, and D) were distinctly recognized by similarity coefficient from at least 0.60 and up to 0.70 (Fig. 6). The first cluster A comprises two accessions of A. breviscapa; it had a high similarity coefficient around 0.70 . Cluster $B$ contains only one morpho-type, A. kerrii, whereas the adjacent cluster $C$ was separated from $A$. kerrii at similarity coefficient around 0.60 . The cluster $C$ contains two samples of $A$. variabilis that had a similarity coefficient about 0.71 . The last cluster D was separated from the other clusters by a similarity coefficient about 0.72 , and formed two subgroups. The subgroup E comprises two accessions of $A$. suddeeana that had a high similarity coefficient around 0.88 . The second subgroup, $F$, is composed of two Argyreia morpho-types which are a single accession of Argyreia 1, and a group of five samples 


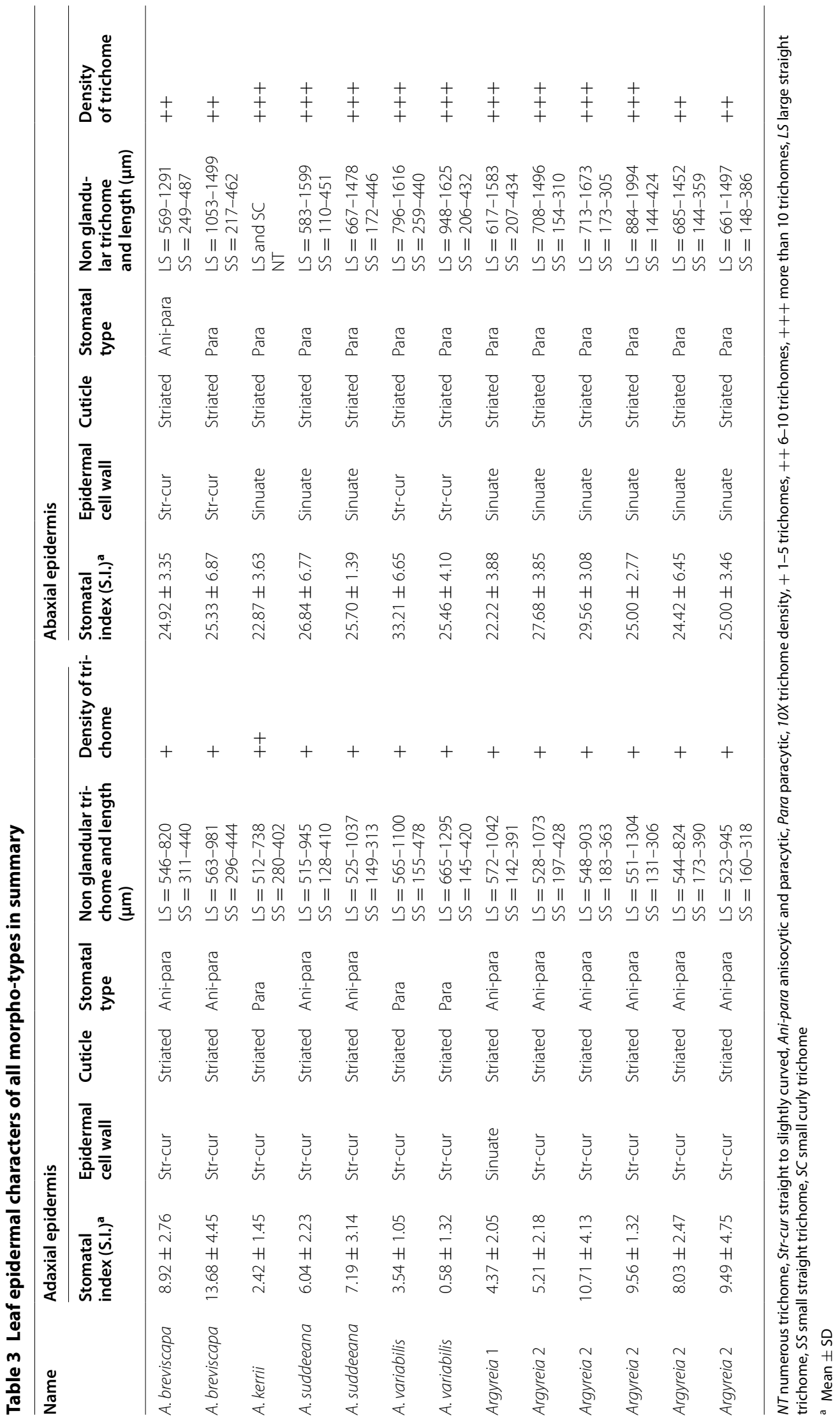


of Argyreia 2 that mutually diverged from each other with the similarity coefficient of 0.74 . Five accessions of Argyreia 2 were obviously separated from Argyreia 1 at around 0.81 of similarity coefficient. Moreover, Argyreia 2 was subdivided into one subgroup (accession numbers 9 and 11) with high similarity coefficient of 0.88 , and a second subgroup (accession numbers 10, 12 and 13) with the same value of similarity $(0.88)$.

\section{Principal component analysis}

The PCA resulting from examination of 24 anatomical characters (Table 5) from 13 Argyreia accessions representing six morpho-types showed the scatter plots of four clusters (Fig. 7). The two accessions of A. breviscapa in cluster $\mathrm{A}$, and also both samples of $A$. variabilis in cluster $\mathrm{C}$ were quite loosely grouped, assuming that they were affected by the first component, while a single accession of $A$. kerrii was isolated from them. The large cluster, $\mathrm{D}$, was formed into two subgroups, E and F. The morphotypes of subgroup E were closely grouped together, whereas those in subgroup $\mathrm{F}$ were widely separated by the first component.

The first two components accounted respectively for 28 and $21.9 \%$ of the total variance (Table 5). In the first component, the one character with high positive factor loading was stomatal index on the abaxial leaf surface (13), while high negative factor loading were the ratio of nonglandular trichome size on abaxial leaf surface (16); ratio of petiole transverse section (18); and blade thickness (23). The second component was weighted heavily positive for epidermal cell walls on abaxial leaf surface (2), and ratio of epidermal cell size in petiole (17), whereas it was negative for ratio of glandular trichome size on abaxial leaf surface (15), and ratio of non-glandular trichome size on abaxial leaf surface (16).

\section{Discussion and conclusions}

The anatomical characters that are informative for identifying these six morpho-types are the epidermal cell walls and trichome types on the leaf surfaces. Moreover, the characters from leaf transverse section were also useful to distinguish each morpho-type such as the shape of adaxial epidermal cells of the leaf blades, the shape of leaf margins and the outline of petioles.

\section{Epidermal cell wall}

Two types of epidermal cell walls are found on both surfaces: straight to slightly curved, and sinuate. This finding is in agreement with the investigations by Metcalfe and Chalk (1950) and Tayade and Patil (2003, 2012c). Argyreia 1 is the only one that possesses sinuate epidermal cell walls on the adaxial surface, whereas most of them have this type of epidermal cell wall on the abaxial side, except $A$. breviscapa and A. variabilis. Argyreia breviscapa is quite similar to Argyreia 1 in terms of morphological characters, especially when compared as pressed and dried herbarium specimen. This study shows that observation of the epidermal cell walls can separate $A$. breviscapa from Argyreia 1, and cluster analysis (CA) further revealed that these two morpho-types are placed in different clusters with similarity coefficient of 0.53 (Fig. 6). This suggests that the two morpho-types are not the same taxon. Further investigations, using different techniques such as molecular genetics, are required for more accurate characterization.

\section{Type of stomata and stomatal index}

Plants in the family Convolvulaceae generally have amphistomatic leaves with paracytic type of stomata, rarely anisocytic (Metcalfe and Chalk 1950; Tayade and Patil 2003, 2012b). The results from this study agreed with the previous researches; nevertheless, anisocytic stomata were present in four morpho-types. The stomatal frequency on both leaf surfaces varies in each morphotype; this is considered systematically significant and may be connected with the ecology of the plants (Stace 1965). Commonly, the stomatal index (SI) might vary depending on light intensity, humidity, and level of air pollution (Nikolić and Mitić 1991). However, both the stomatal frequency and stomatal index were treated as useful characters for diagnostic purposes (Metcalfe and Chalk 1979).

\section{Trichomes and cuticular pattern on leaf surfaces}

Trichomes are known to play essential roles in protecting plants from chilling, drought, UV radiation, disease infection, and particularly against insect herbivory (Liakoura et al. 1997; Pfeiffer et al. 2003). Furthermore, trichome density may vary due to genetic as well as environmental factors, including water and mineral nutrients or the accumulation of water which alters leaf size (Johnson 1975; Wilkens et al. 1996; Roy et al. 1999).

Both glandular and non-glandular trichomes are present in Argyreia. Trichomes are normally present on both leaf surfaces in the six morpho-types studied. Finding glandular peltate trichomes in all morpho-types corresponded to reports in the previous studies by Tayade and Patil (2012a, c). Non-glandular trichomes, both large and small straight unicellular types, are found in all the morpho-types, but the large straight and small curly trichomes occur only on the abaxial surface of $A$. kerrii. The CA result also confirmed that $A$. kerrii is separated from cluster $C$ with a 0.602 similarity coefficient (Fig. 6).

Cuticular striations occur in all six morpho-types studied. The diversity of patterning on the cuticular layers can be conveniently employed in taxonomic delineations in this family, as suggested by Tayade and Patil (2003). Our 

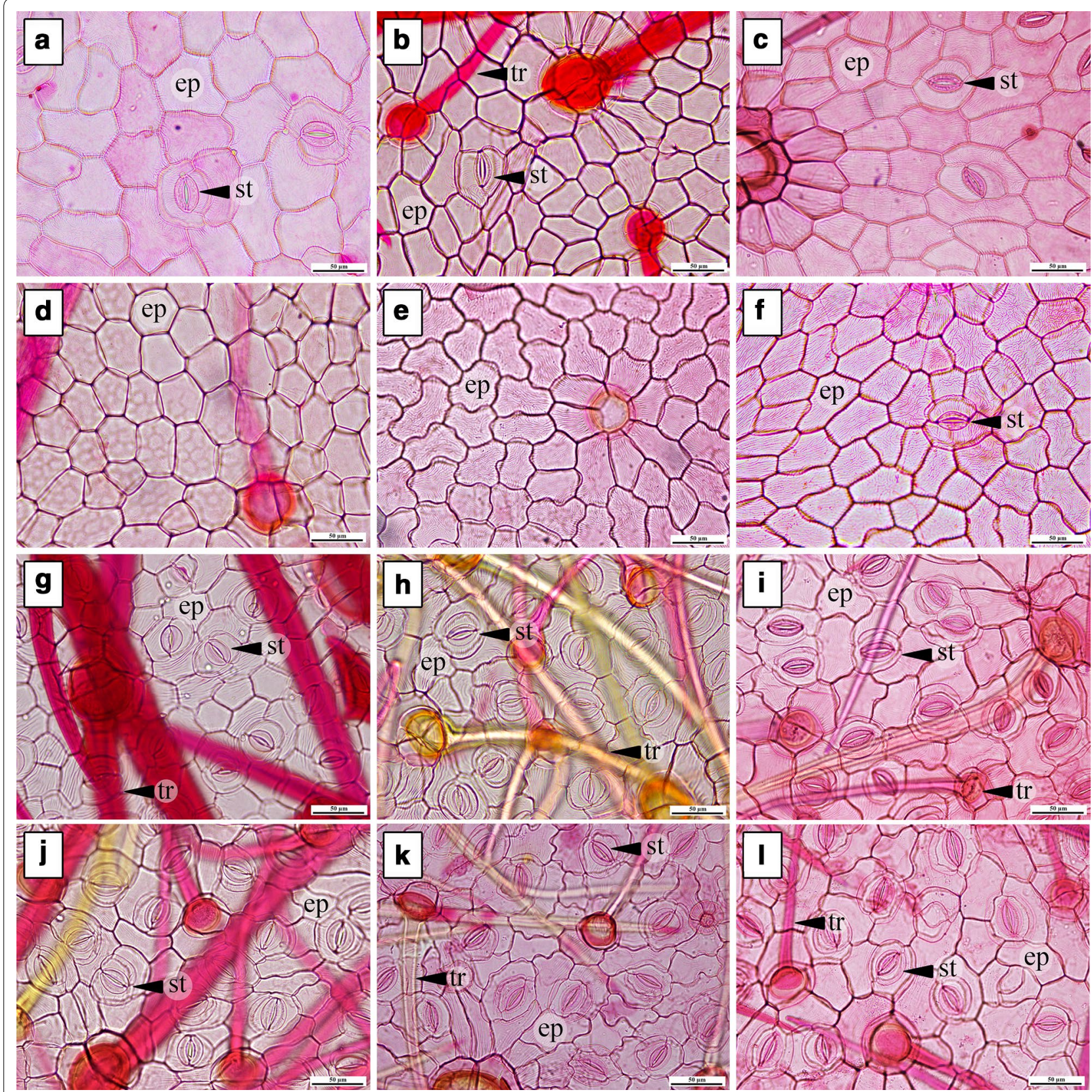

Fig. 1 The epidermal cell walls on adaxial (a-f) and abaxial leaf surfaces (g-I) under light microscope (LM). a A. breviscapa, b A. kerrii, c A. suddeeana, d A. variabilis and $\mathbf{f}$ Argyreia 2, straight to slightly curved walls. e Argyreia 1, sinuate walls. $\mathbf{g}$ A. breviscapa and $\mathbf{j}$ A. variabilis, straight to slightly curved. h A. kerrii, i A. suddeeana, $\mathbf{k}$ Argyreia 1 and I Argyreia 2, sinuate (ep epidermal cell, st stomata, tr trichome). Scale bar $50 \mu \mathrm{m}$

recent paper showed that the cutin layer can distinguish two morphologically similar species, A. albiflora and $A$. wallichii (Staples et al. 2015).

\section{Transverse sections of leaf blade and petiole}

Characters obtained from leaf transverse sections in this research are in agreement with previous studies (Metcalfe and Chalk 1950; Tayade and Patil 2012b, c) that demonstrated all Argyreia leaves are dorsiventral; the leaf blades of every morpho-type have one layer of epidermis; and the mesophyll is composed of palisade and spongy cells. Additionally, there are some dark-staining deposits, which could be flavonoids or alkaloids, in some of the epidermal cells on the adaxial surface. This occurrence corresponded to the study of loline alkaloids in Argyreia mollis (Burm.f.) Choisy, which also can be found in roots 

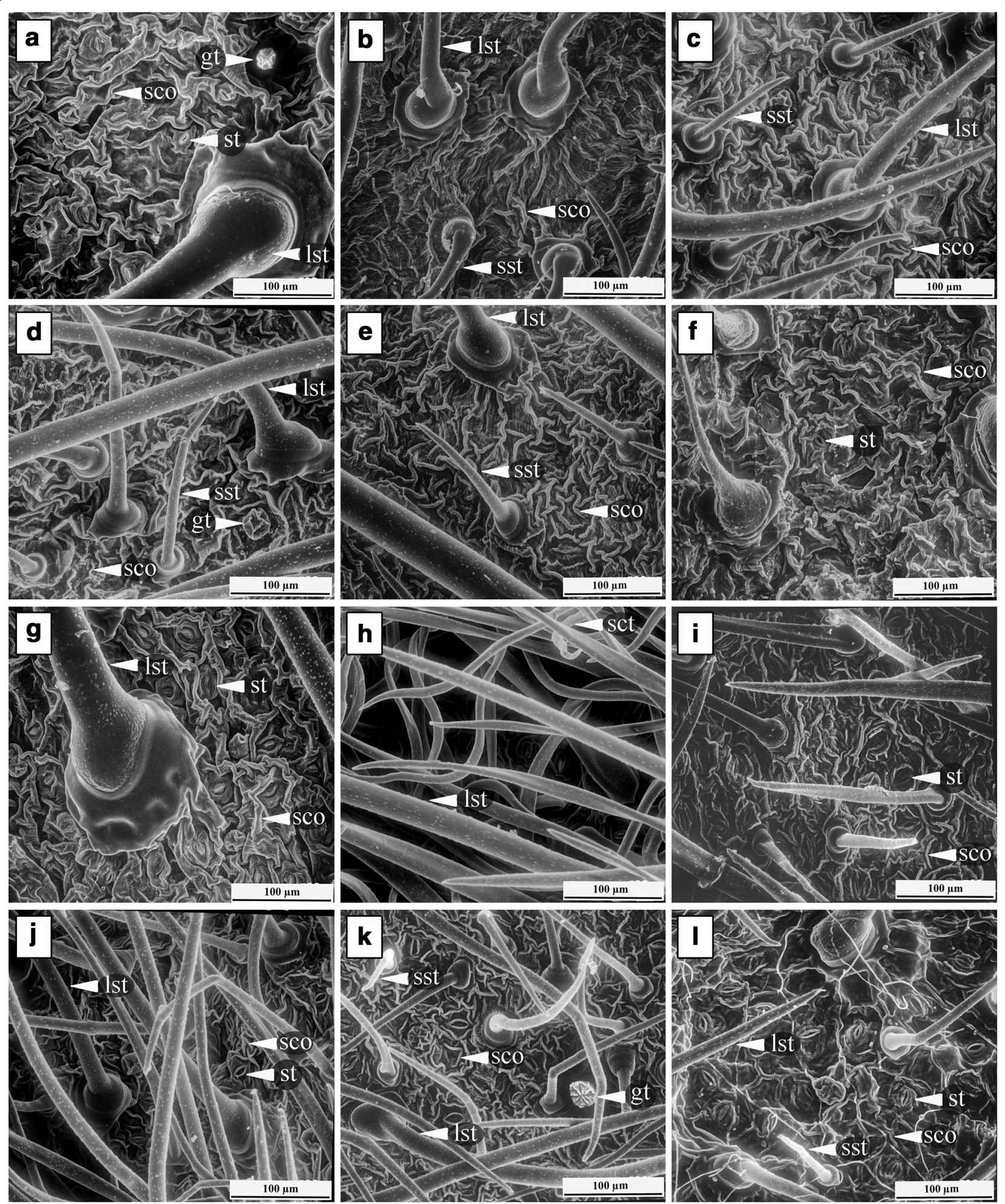

Fig. 2 Cuticle ornamentation on adaxial (a-f) and abaxial leaf surfaces $(\mathbf{g}-\mathbf{I})$ from SEM. $\mathbf{a}, \mathbf{g}$ A. breviscapa, $\mathbf{b}, \mathbf{h}$ A. kerrii, $\mathbf{c}, \mathbf{i}$ A. suddeeana, $\mathbf{d}, \mathbf{j}$ A.

variabilis, e, $\mathbf{k}$ Argyreia 1 and $\mathbf{f}$ I Argyreia 2 (gt glandular trichome, Ist large straight trichome, sst small straight trichome, sct small curly trichome, st stomata, sco striate cuticular ornamentation). Scale bar $100 \mu \mathrm{m}$ 

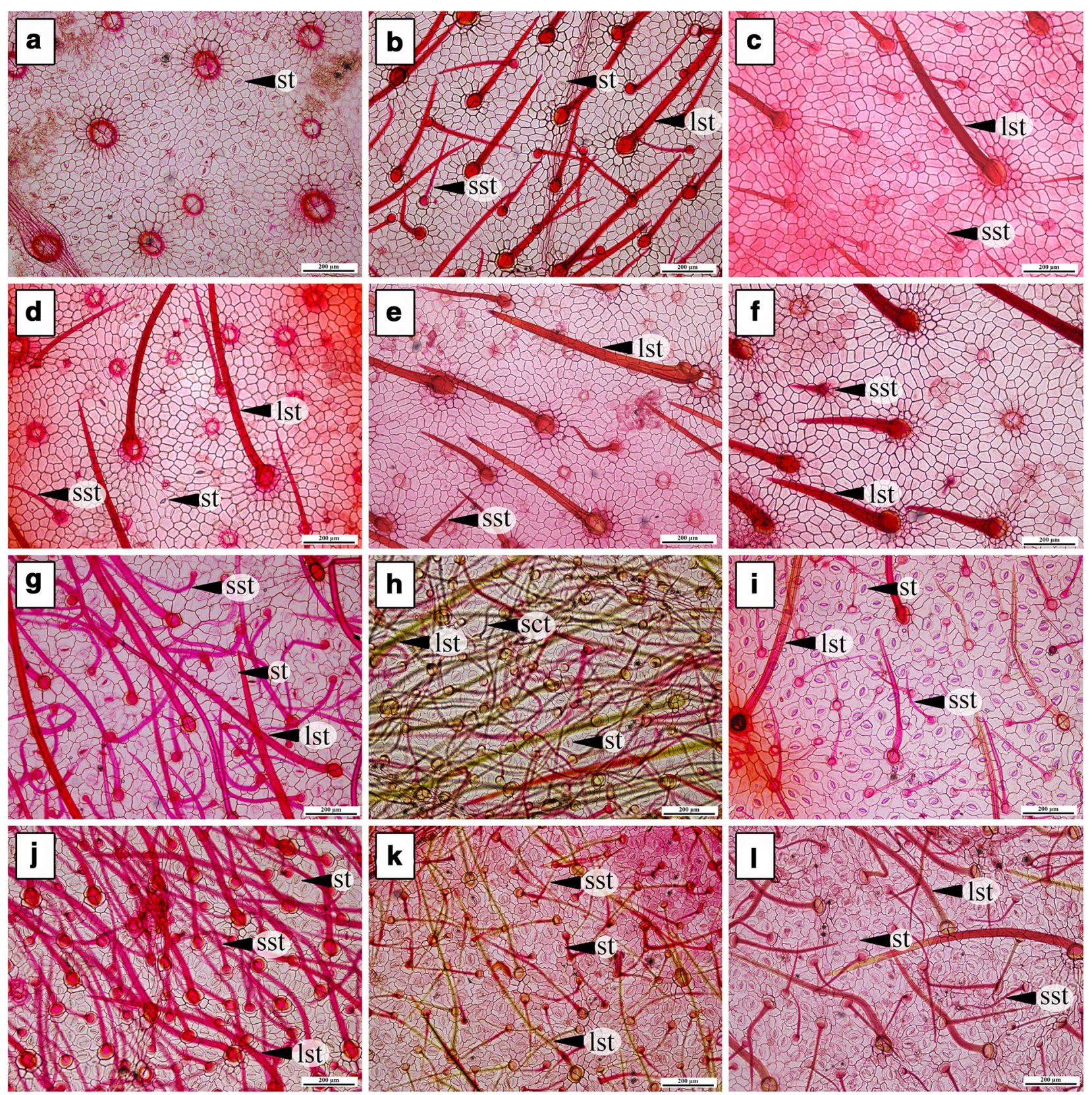

Fig. 3 Trichomes on adaxial (a-f) and abaxial leaf surfaces (g-I) under light microscopy (LM). a, g A. breviscapa, b, h A. kerrii, c, i A. suddeeana, d, $\mathbf{j}$ A. variabilis, e, $\mathbf{k}$ Argyreia 1 and $\mathbf{f}$ I Argyreia 2 (Ist large straight trichome, sst small straight trichome, sct small curly trichome, st stomata). Scale bar $200 \mu \mathrm{m}$

and aerial vegetative parts of plants (Tofern et al. 1999; Mann et al. 1999; Tayade and Patil 2012b).

The epidermal cell shapes of leaf blade in transverse section of A. variabilis show long and narrow shapes and its leaf margins are acute, which is different from the other morpho-types. This coincides with phenetic result that show two accessions of $A$. variabilis separated from cluster B (Fig. 6) in cluster analysis by similarity coefficient of 0.602 and forming a distinct cluster $\mathrm{C}$. The epidermal cell shape character and results from phenetic analyses can be used to point out that Argyreia 2 is different from A. variabilis.

The vascular tissue of the petiole in the family Convolvulaceae commonly exhibits bicollateral bundles (Metcalfe and Chalk 1950; Tayade and Patil 2012a, c). The results from this research correspond to the prior studies. 


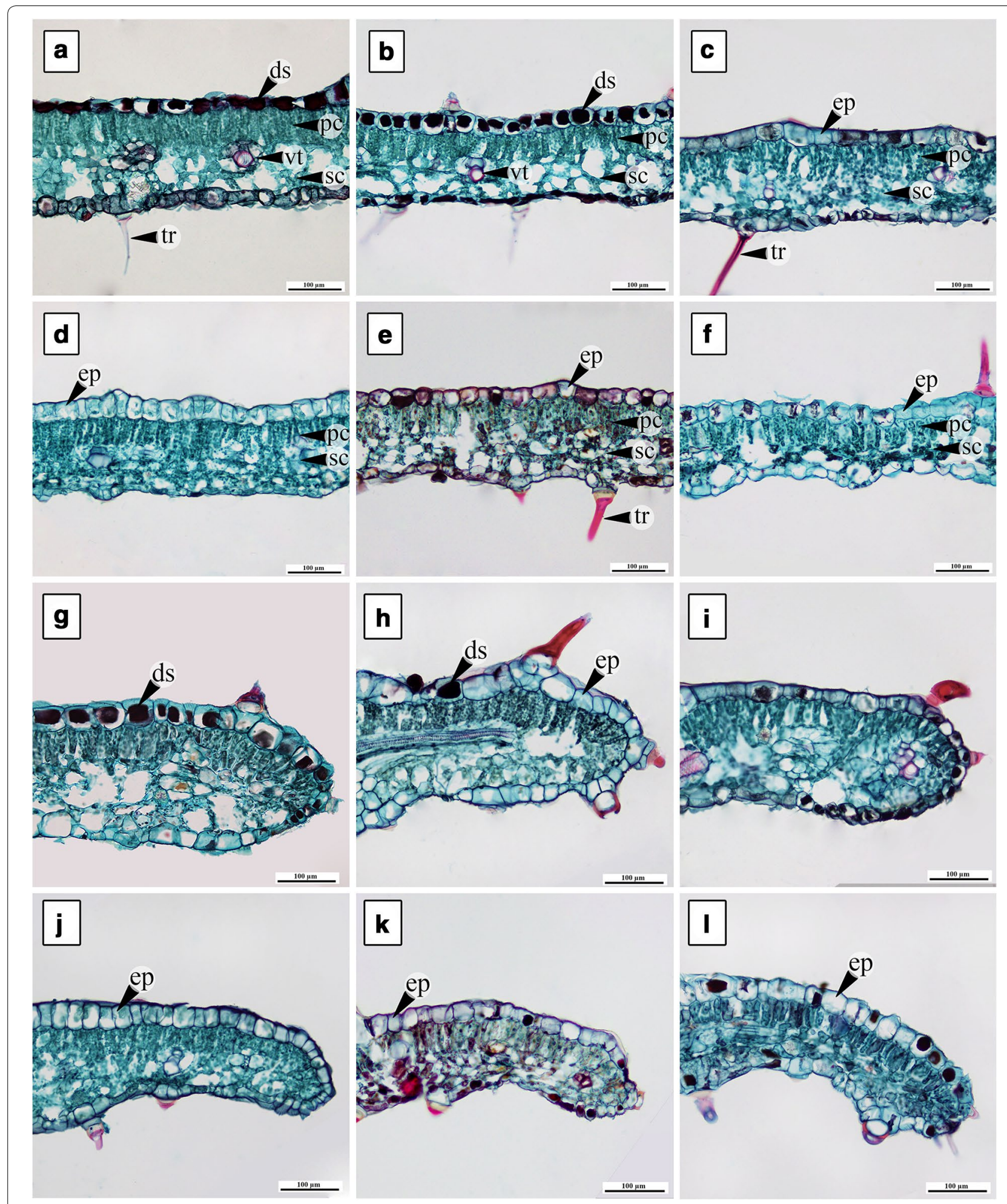

Fig. 4 Transverse sections of leaf blade (a-f) and leaf margin ( $\mathbf{g}-\mathbf{I})$. a, $\mathbf{g}$ A. breviscapa, $\mathbf{b}, \mathbf{h}$ A. kerrii, $\mathbf{c}, \mathbf{i}$ A. suddeeana, $\mathbf{d}$, j A. variabilis, e, $\mathbf{k}$ Argyreia 1 and $\mathbf{f}$, I Argyreia 2 (ds dark-staining deposit, ep epidermal cell, pc palisade cell, sc spongy cell, tr trichome, vt vascular tissue). Scale bar $100 \mu \mathrm{m}$ 


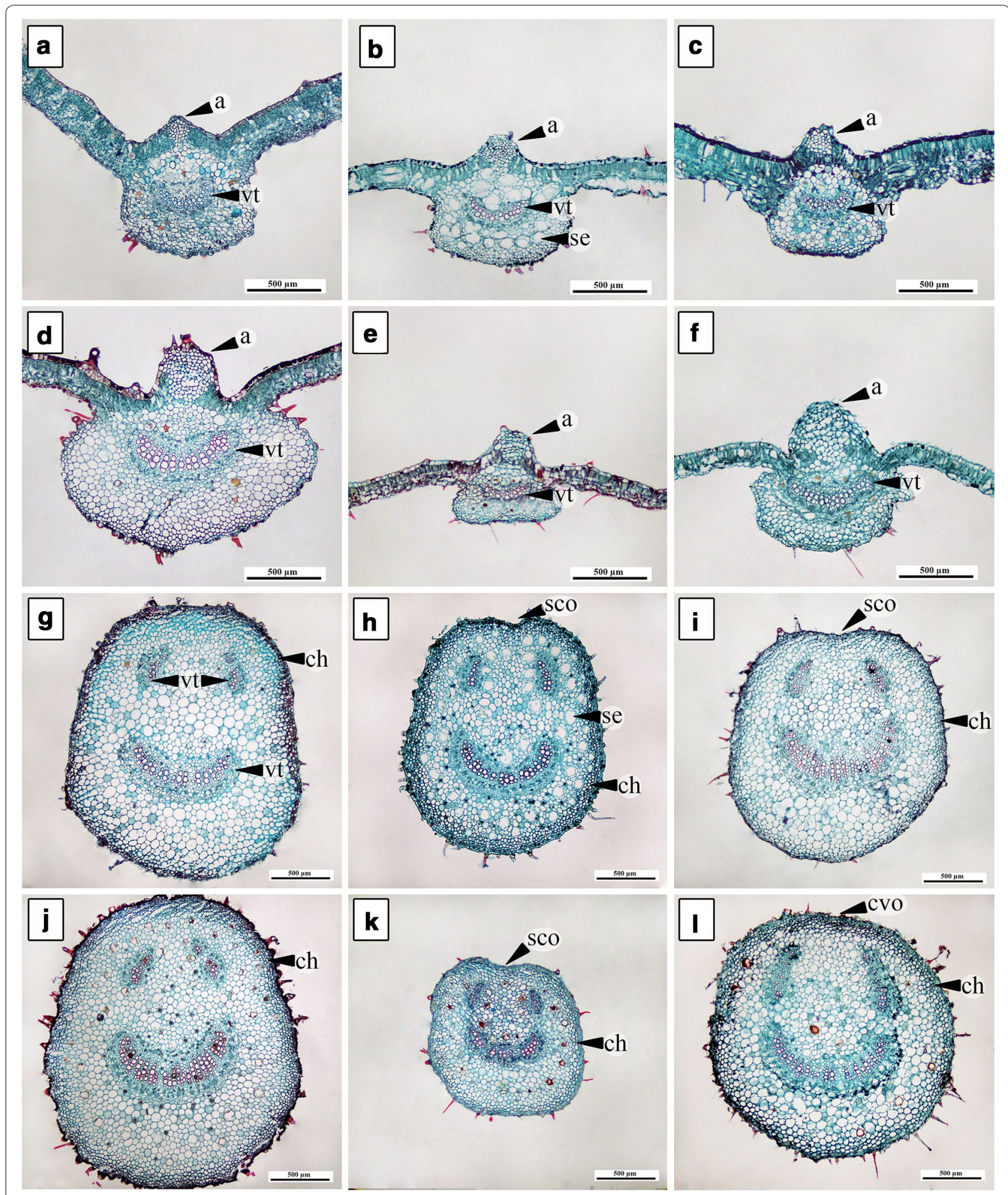

Fig. 5 Transverse sections of midrib (a-f) and petiole ( $\mathbf{g}-\mathbf{I})$. a, $\mathbf{g}$ A. breviscapa, b, h A. kerrii, $\mathbf{c}, \mathbf{i}$ A. suddeeana, $\mathbf{d}, \mathbf{j}$ A. variabilis, e, $\mathbf{k}$ Argyreia 1 and $\mathbf{f}, \mathbf{I}$ Argyreia 2 ( $a$ adaxial curvature, ch chlorenchyma cell, cvo convex outline, sco slightly concave outline, se secretory cavity, vt vascular tissue). Scale bar $500 \mu \mathrm{m}$ 
Table 4 Leaf and petiole transverse section characters in summary

\begin{tabular}{|c|c|c|c|c|c|c|c|c|}
\hline \multirow[t]{2}{*}{ Name } & \multirow[t]{2}{*}{$\begin{array}{l}\text { Petiole } \\
\text { outline }\end{array}$} & \multicolumn{2}{|c|}{$\begin{array}{l}\text { Cross-sectional petiole } \\
\text { size }(\mathrm{mm})\end{array}$} & \multirow[t]{2}{*}{$\begin{array}{l}\text { Midrib outline and adaxial } \\
\text { curvature }\end{array}$} & \multicolumn{2}{|c|}{$\begin{array}{l}\text { Cross-sectional midrib } \\
\text { size }(\mathrm{mm})\end{array}$} & \multirow[t]{2}{*}{$\begin{array}{l}\text { Leaf blade } \\
\text { width }(\mu \mathrm{m})\end{array}$} & \multirow[t]{2}{*}{$\begin{array}{l}\text { Leaf } \\
\text { margins }\end{array}$} \\
\hline & & Width & Height & & Width & Height & & \\
\hline A. breviscapa & Convex & $2.02 \pm 0.05$ & $2.10 \pm 0.04$ & Convex with acute adaxial curvature & $1.17 \pm 0.24$ & $1.03 \pm 0.08$ & $269.40 \pm 35.64$ & Round \\
\hline A. breviscapa & Convex & $1.98 \pm 0.02$ & $2.28 \pm 0.11$ & Convex with acute adaxial curvature & $1.19 \pm 0.08$ & $1.14 \pm 0.07$ & $211.77 \pm 7.84$ & Round \\
\hline A. kerrii & Concave & $1.73 \pm 0.03$ & $1.76 \pm 0.23$ & Convex with round adaxial curvature & $1.01 \pm 0.06$ & $0.95 \pm 0.05$ & $198.70 \pm 45.96$ & Round \\
\hline A. suddeeana & Concave & $2.01 \pm 0.17$ & $2.06 \pm 0.12$ & Convex with round adaxial curvature & $1.40 \pm 0.29$ & $1.21 \pm 0.15$ & $183.03 \pm 3.46$ & Round \\
\hline A. suddeeana & Concave & $1.51 \pm 0.15$ & $1.65 \pm 0.12$ & Convex with round adaxial curvature & $0.96 \pm 0.31$ & $0.92 \pm 0.08$ & $291.23 \pm 28.90$ & Round \\
\hline A. variabilis & Convex & $2.24 \pm 0.09$ & $2.77 \pm 0.39$ & Convex with round adaxial curvature & $1.33 \pm 0.12$ & $1.34 \pm 0.12$ & $177.60 \pm 29.23$ & Acute \\
\hline A. variabilis & Convex & $1.98 \pm 0.58$ & $2.34 \pm 0.59$ & Convex with round adaxial curvature & $1.52 \pm 0.20$ & $1.26 \pm 0.15$ & $244.87 \pm 44.14$ & Acute \\
\hline Argyreia 1 & Concave & $1.47 \pm 0.18$ & $1.24 \pm 0.15$ & Convex with round adaxial curvature & $0.85 \pm 0.26$ & $0.71 \pm 0.10$ & $162.53 \pm 11.59$ & Round \\
\hline Argyreia 2 & Convex & $1.99 \pm 0.19$ & $2.20 \pm 0.02$ & Convex with round adaxial curvature & $1.34 \pm 0.17$ & $1.26 \pm 0.13$ & $191.53 \pm 9.76$ & Round \\
\hline Argyreia 2 & Convex & $1.44 \pm 0.09$ & $1.82 \pm 0.02$ & Convex with round adaxial curvature & $0.91 \pm 0.09$ & $0.94 \pm 0.06$ & $171.83 \pm 22.91$ & Round \\
\hline Argyreia 2 & Convex & $1.52 \pm 0.12$ & $1.84 \pm 0.04$ & Convex with round adaxial curvature & $0.98 \pm 0.12$ & $1.05 \pm 0.07$ & $174.57 \pm 33.96$ & Round \\
\hline Argyreia 2 & Convex & $1.43 \pm 0.09$ & $1.83 \pm 0.07$ & Convex with round adaxial curvature & $0.91 \pm 0.10$ & $1.05 \pm 0.01$ & $156.73 \pm 14.62$ & Round \\
\hline Argyreia 2 & Convex & $1.73 \pm 0.03$ & $1.73 \pm 0.23$ & Convex with round adaxial curvature & $0.95 \pm 0.09$ & $0.92 \pm 0.04$ & $220.97 \pm 16.15$ & Round \\
\hline
\end{tabular}

Shape of the Argyreia petiole in transverse section is convex (Fig. 5g, j, l) or slightly concave (Fig. 5h, i, k) on the adaxial side, as also seen in the study of genus Merremia Dennst. ex. Endl. (Pisuttimarn et al. 2013). In our results, half the taxa have convex petiole shape (A. breviscapa, A. variabilis, and Argyreia 2), whereas in A. kerrii, A. suddeeana and Argyreia 1, petioles have a concave shape (about $1 / 6$ of the length of the petiole). The result from CA indicated that A. suddeeana, Argyreia 1, and Argyreia 2 were grouped together in the same cluster (D), however, A. suddeeana was separated from this group forming a subgroup $\mathrm{E}$, at similarity coefficient

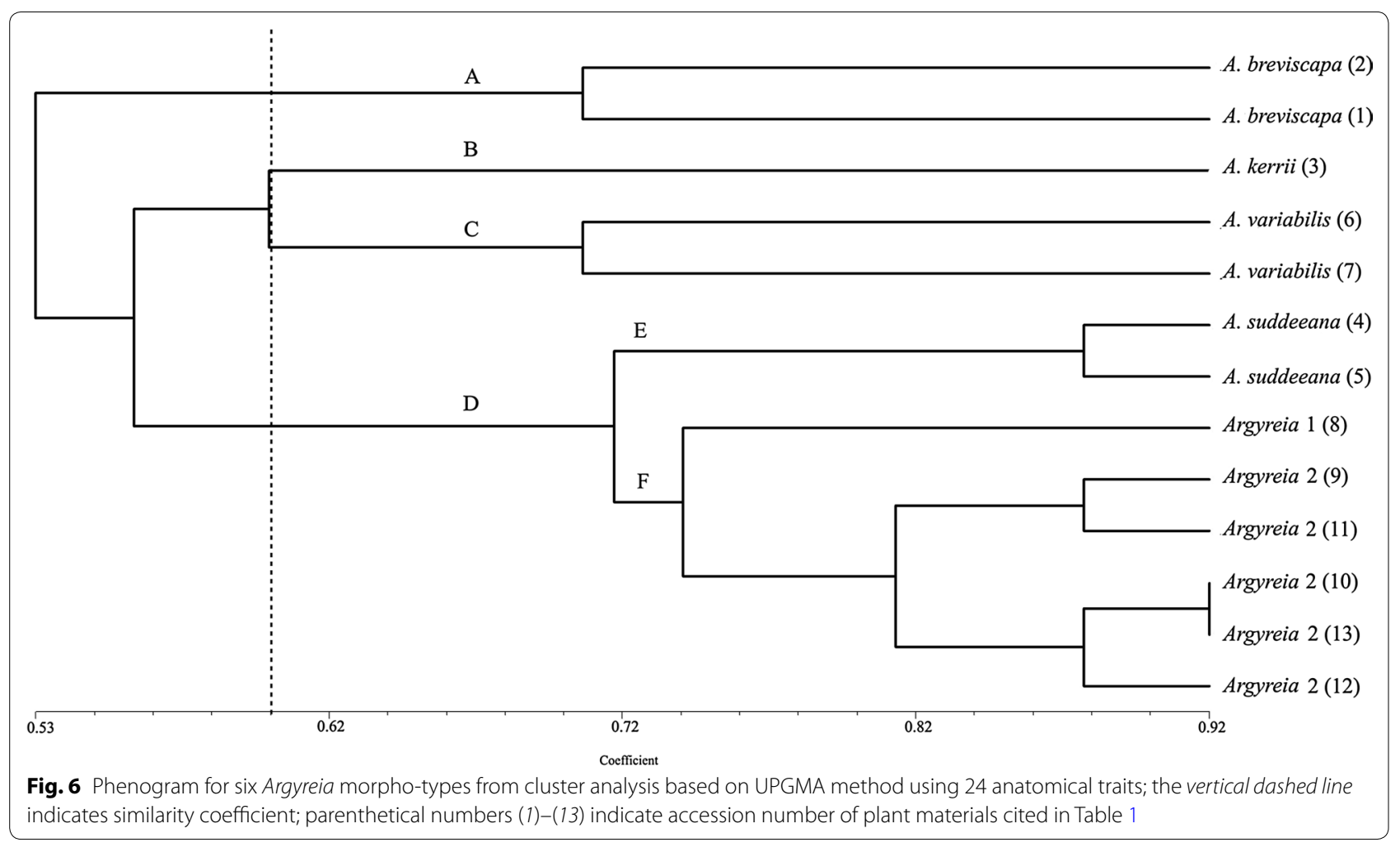


about 0.718 (Fig. 6). Therefore, the outline of petiole can be used to separate A. suddeeana from Argyreia 2.

Druse crystals (calcium oxalate) are commonly found in petiole, midrib, and leaf blade of all six morpho-types, which agrees with the previous investigations by Metcalfe and Chalk (1950), Sayeedud-Din (1953) and Tayade and Patil (2012a, c). The druse crystal has many functions in plants including calcium regulation, ion balance, tissue support, plant protection, detoxification and light assembly and reflection (Franceschi and Horner 1980; Nakata 2003). Recent research about druse crystals in a $\mathrm{C}_{4}$ plant, Amaranthus hybridus L., revealed that the plant

Table 5 Factor loading and cumulative eigenvalue percentage received from 24 leaf anatomical characters

\begin{tabular}{|c|c|c|}
\hline \multirow[t]{2}{*}{ Anatomical characters } & \multicolumn{2}{|c|}{ Component } \\
\hline & 1 & 2 \\
\hline 1. Epidermal cell wall on adaxial leaf surface & 0.024 & -0.086 \\
\hline 2. Epidermal cell wall on abaxial leaf surface & 0.071 & 0.397 \\
\hline $\begin{array}{l}\text { 3. Types of non-glandular trichome on abaxial leaf } \\
\text { surface }\end{array}$ & 0.051 & 0.059 \\
\hline 4. Shape of petiole & 0.076 & 0.131 \\
\hline 5. Midrib outline and adaxial curvature & -0.217 & 0.153 \\
\hline 6. Leaf margin shape & 0.146 & 0.245 \\
\hline 7. Ratio of adaxial leaf epidermal cell size & 0.051 & 0.059 \\
\hline 8. Stomatal index (SI) on adaxial leaf surface & -0.193 & 0.067 \\
\hline 9. Ratio of stomatal size on adaxial leaf surface & -0.124 & 0.281 \\
\hline $\begin{array}{l}\text { 10. Ratio of glandular trichome size on adaxial leaf } \\
\text { surface }\end{array}$ & -0.202 & 0.118 \\
\hline $\begin{array}{l}\text { 11. Ratio of non-glandular trichome size on adaxial } \\
\text { leaf surface }\end{array}$ & 0.000 & -0.163 \\
\hline 12. Ratio of abaxial leaf epidermal cell size & 0.093 & 0.172 \\
\hline 13. Stomatal index (SI) on abaxial leaf surface & 0.222 & 0.159 \\
\hline 14. Ratio of stomatal size on abaxial leaf surface & 0.043 & 0.113 \\
\hline $\begin{array}{l}\text { 15. Ratio of glandular trichome size on abaxial leaf } \\
\text { surface }\end{array}$ & -0.197 & -0.304 \\
\hline $\begin{array}{l}\text { 16. Ratio of non-glandular trichome size on abaxial } \\
\text { leaf surface }\end{array}$ & -0.448 & -0.229 \\
\hline 17. Ratio of epidermal cell size in petiole & 0.122 & 0.390 \\
\hline 18. Ratio of petiole transverse section & -0.430 & 0.026 \\
\hline $\begin{array}{l}\text { 19. Ratio of palisade mesophyll cell size in leaf trans- } \\
\text { verse section }\end{array}$ & 0.076 & 0.063 \\
\hline $\begin{array}{l}\text { 20. Ratio of spongy mesophyll cell size in leaf trans- } \\
\text { verse section }\end{array}$ & -0.114 & 0.284 \\
\hline $\begin{array}{l}\text { 21. Ratio of adaxial epidermal cell size in leaf transverse } \\
\text { section }\end{array}$ & 0.177 & 0.103 \\
\hline $\begin{array}{l}\text { 22. Ratio of abaxial epidermal cell size in leaf transverse } \\
\text { section }\end{array}$ & 0.108 & -0.245 \\
\hline 23. Blade thickness & -0.504 & 0.243 \\
\hline 24. Ratio of midrib thickness & 0.083 & -0.156 \\
\hline Eigenvalue & 1.3776 & 1.0784 \\
\hline Cumulative $\%$ of eigenvalue & 28 & 49.9 \\
\hline
\end{tabular}

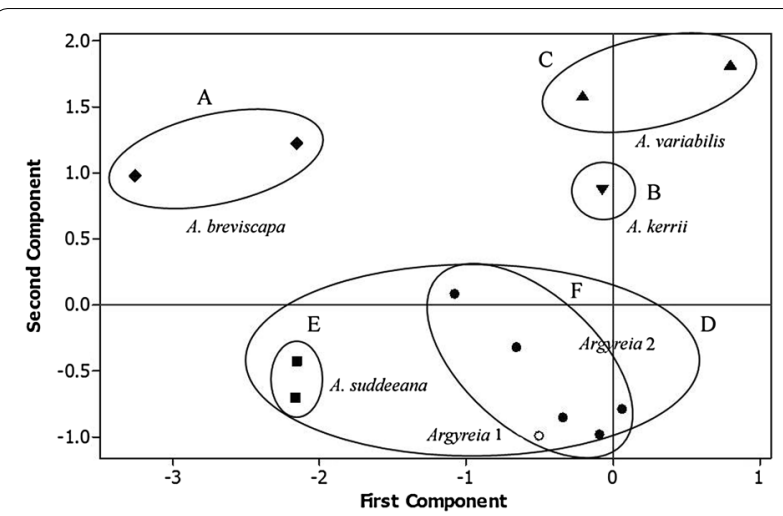

Fig. 7 The scattered plot of first and second components obtained from principal component analysis (PCA) based on 24 anatomical traits. Group $A, B, C, D$ and subgroups $E$ and $F$ corresponding to the phenogram in Fig. 6

used calcium oxalate crystals as a non-atmospheric carbon source in photosynthesis assimilation during the day, especially in drought condition (Tooulakou et al. 2016). In the daytime, druse crystals were degraded and provided subsidiary carbon used in photosynthesis under ambient conditions that caused stomatal closure (for preventing water loss). Moreover, these crystals were recovered during the night as a biochemical carbon reservoir.

Numerous secretory cavities in the ground tissue of the petiole and midrib are also observed in A. kerrii, in agreement with previous researches, which reported that plants in this family possess secretory cavities in the ground tissue of leaf, petiole, and stem (Metcalfe and Chalk 1950; Sayeedud-Din 1953; Tayade and Patil 2012a, c).

Although the results from this study were consistent with earlier anatomical studies they incrementally increase the fundamental knowledge base about the genus Argyreia and point the way for further study. Rather few plant samples in genus Argyreia were examined previously; in this study, we investigated several more Argyreia taxa that have not been studied before. Furthermore, our data demonstrate that anatomical traits can provide informative characters that have a useful role for plant identification. Argyreia has proven to be an extraordinarily complex genus and species delimitation is difficult, especially in the complexes of vegetatively similar species where floral characters have been the only reliable method to discriminate taxa. Accordingly, evidence from methods and techniques outside the usual morphological ones must be explored to determine whether they afford taxonomically informative characters. Since the genus Argyreia is one of the larger genera in the family Convolvulaceae comprising around 135 species (Staples and Traiperm 2017) the results from our study expand 
the baseline for understanding morphological and anatomical diversity within and between species.

\section{Authors' contributions}

PT created the study topic, collected the plants, planned the study, guided all lab work, drafted, revised and developed the manuscript, prepared the manuscript for submission. JC analyzed the anatomical data and drafted some parts of the manuscript. PN analyzed the CA and PCA data and drafted some parts of the manuscript. GWS planned the study, guided taxonomic identifications, provided important taxonomic literatures, drafted, revised, developed the manuscript and polished the English. SCS guided lab work. All authors read and approved the final manuscript.

\section{Author details}

${ }^{1}$ Department of Plant Science, Faculty of Science, Mahidol University, Rama VI Road, Ratchathewi, Bangkok 10400, Thailand. ${ }^{2}$ Department of Pharmaceutical Botany, Faculty of Pharmacy, Mahidol University, Bangkok 10400, Thailand. ${ }^{3}$ HRA, Herbarium, Royal Botanic Gardens, Kew, Richmond, Surrey TW9 3AE, UK.

\section{Acknowledgements}

We would like to thank the Department of Plant Science, Faculty of Science, Mahidol University for laboratory facilities. Thanks also to Wirata Rujichaipimon for help in preparing the colour photos. Traiperm wishes to acknowledge the Thailand Research Fund (TRF), RSA5880022 and the Faculty of Science, Mahidol University for financial support. GS gratefully acknowledges funding support from Faculty of Graduate Studies, Mahidol University, which facilitated our collaboration.

\section{Competing interests}

The authors declare that they have no competing interests.

\section{Funding}

The Thailand Research Fund (TRF), RSA5880022, the Faculty of Science and Faculty of Graduate Studies, Mahidol University.

\section{Publisher's Note}

Springer Nature remains neutral with regard to jurisdictional claims in published maps and institutional affiliations.

\section{Received: 14 April 2017 Accepted: 23 May 2017}

Published online: 02 June 2017

\section{References}

Aghababaeyan E, Pakravan M, Ghahremaninejad F (2014) Anatomical study and pollen micromorphology of Onopordum L. in Iran. Notulae Scientia Biologicae 6(1):66-76

Arthan W, Traiperm P, Gale SW, Norsaengsri M, Kethirun L (2016) Re-evaluation of the taxonomic status of Hackelochloa (Poaceae) based on anatomical and phenetic analyses. Bot J Linn Soc 181(2):224-245

Breitwieser I, Ward JM (1993) Systematics of New Zealand Inuleae (Compositae-Asteraceae)-3 numerical phenetic analysis of leaf anatomy and flavonoids. N Z J Bot 31(1):43-58

De Faria AP, Wendt T, Brown GK (2010) A revision of Aechmea subgenus Macrochordion (Bromeliaceae) based on phenetic analyses of morphological variation. Bot J Linn Soc 162(1):1-27

Franceschi VR, Horner HT (1980) Calcium oxalate crystals in plants. Bot Rev 46(4):361-427

Jayarathna SP, Senanayake SP, Rajapakse S, Jayasekera LR (2016) Phenetic variation and preliminary phytochemical screening of Piper species in Sri Lanka. J Agric Sci 11(3):155-163

Johansen DA (1940) Plant microtechnique, 1st edn. McGraw-Hill Book, New York

Johnson HB (1975) Plant pubescence: an ecological perspective. Bot Rev 41:233-258
Liakoura V, Stefanou M, Manetas Y, Cholevas C, Karabourniotis G (1997) Trichome density and its UV-B protective potential are affected by shading and leaf position on the canopy. Environ Exp Bot 38(3):223-229

Mann P, Tofern B, Kaloga M, Eich E (1999) Flavonoid sulfates from the Convolvulaceae. Phytochemistry 50(2):267-271

Metcalfe CR, Chalk L (1950) Convolvulaceae. In: Metcalfe CR, Chalk L (eds) Anatomy of the dicotyledons, vol 2. Clarendon Press, Oxford, pp 954-964

Metcalfe CR, Chalk L (1979) Anatomy of the dicotyledons, vol 1, 2nd edn. Clarendon Press, Oxford

Minitab (2010) Minitab 16 statistical software. Minitab Inc, State College

Moraes TM, Rabelo GR, Alexandrino CR, Silva Neto SJ, Da Cunha M (2011) Comparative leaf anatomy and micromorphology of Psychotria species (Rubiaceae) from the Atlantic Rainforest. Acta Bot Bras 25(1):178-190

Nakata PA (2003) Advances in our understanding of calcium oxalate crystal formation and function in plants. Plant Sci 164(6):901-909

Nikolić T, Mitić B (1991) Phenetic relationships within populations of Iris illyrica, I. pallida and I. pseudopallida (Iridaceae) with regard to morphological characteristics of epidermis. Acta Bot Croat 50(1):99-106

Pant DD, Bhatnagar S (1975) Morphological studies in Argyreia Lour. (Convolvulaceae). Bot J Linn Soc 70(1):45-69

Pfeiffer TW, Peyyala R, Ren Q, Ghabrial SA (2003) Increased soybean pubescence density: yield and soybean mosaic virus resistance effects. Crop Sci 43:2071-2076

Pisuttimarn P, Traiperm P, Pornpongrungrueng P (2013) Comparative anatomy of Merremia section Xanthips (Convolvulaceae) in Thailand. In: Proceedings in the national graduate research conference 29th (NGRC29) (in Thai), pp 93-101

Rohlf FJ (2000) NTSYS-pc: numerical taxonomy and multivariate analysis system, version 2.1. Exeter Software, New York

Roy BA, Stanton ML, Eppley SM (1999) Effects of environmental stress on leaf hair density and consequences for selection. J Evol Biol 12(6):1089-1103

Salisbury EJ (1927) On the causes and ecological significance of stomatal frequency, with special reference to the woodland flora. Philos Trans R Soc Lond 216:1-65

Sayeedud-Din M (1953) Observations on the anatomy of some of the Convolvulaceae. Bot J Linn Soc 37:106-109

Stace CA (1965) Cuticular studies as an aid in plant taxonomy. Bull Brit Mus (Nat Hist) Bot 4:1-78

Staples GW, Traiperm P (2008) New species, new combinations, and new records in Convolvulaceae for the Flora of Thailand. Thai Forest Bull Bot 36:86-108

Staples GW, Traiperm P (2017) A nomenclatural review of Argyreia (Convolvulaceae). Taxon 66:445-477

Staples GW, Traiperm P, Chow J (2015) Another new Thai Argyreia species (Convolvulaceae). Phytotaxa 204(3):223-229

Tayade SK, Patil DA (2003) Foliar epidermal features and their taxonomic significance in the genus Argyreia Lour. (Convolvulaceae). J Swam Bot Club 20:15-18

Tayade SK, Patil DA (2012a) Anatomical studies of stem in some species of Convolvulaceae. Int J Sci Pharm Educ Res 1(2):42-46

Tayade SK, Patil DA (2012b) Leaf anatomical studies in some species of Convolvulaceae. Life Sci Leafl 3:64-74

Tayade SK, Patil DA (2012c) The family Convolvulaceae: anatomical conspectus. World J Sci Technol 2(6):42-50

Thadeo M, Azevedo AA, Meira RM (2014) Foliar anatomy of neotropical Salicaceae: potentially useful characters for taxonomy. Plant Syst Evol 300(9):2073-2089

Tofern B, Kaloga M, Witte L, Hartmann T, Eich E (1999) Occurrence of loline alkaloids in Argyreia mollis (Convolvulaceae). Phytochemistry 51(8):1177-1180

Tooulakou G, Giannopoulos A, Nikolopoulos D, Bresta P, Dotsika E, Orkoula MG, Kontoyiannis CG, Fasseas C, Liakopoulos G, Klapa MI, Karabourniotis G (2016) Alarm photosynthesis: calcium oxalate crystals as an internal $\mathrm{CO}_{2}$ source in plants. Plant Physiol 171(4):2577-2585

Traiperm P, Staples GW (2014) A new endemic Thai species of Argyreia (Convolvulaceae). Phytotaxa 164(4):281-285

Wilkens RT, Shea GO, Halbreich S, Stamp NE (1996) Resource availability and the trichome defense of tomato plants. Oecologia 106(2):181-191 